Cahiers d'études italiennes

23 | 2016

FILIgRANA

Intuizione e forma. André Jolles: vita, opere, posterità

\title{
Metamorphosis. Jolles and Huizinga and Comparative Literature
}

Metamorphosis : Jolles et Huizinga et la littérature comparée

\section{Willem Otterspeer}

\section{OpenEdition}

\section{Journals}

Electronic version

URL: http://journals.openedition.org/cei/3055

DOI: 10.4000/cei.3055

ISSN: 2260-779X

\section{Publisher}

UGA Éditions/Université Grenoble Alpes

\section{Printed version}

Date of publication: 30 December 2016

Number of pages: $19-28$

ISBN: 978-2-84310-337-7

ISSN: 1770-9571

\section{Electronic reference}

Willem Otterspeer, "Metamorphosis. Jolles and Huizinga and Comparative Literature", Cahiers d'études italiennes [Online], 23 | 2016, Online since 23 January 2017, connection on 26 March 2021. URL: http:// journals.openedition.org/cei/3055 ; DOI: https://doi.org/10.4000/cei.3055 


\title{
METAMORPHOSIS. JOLLES AND HUIZINGA AND COMPARATIVE LITERATURE
}

\author{
Willem Otterspeer \\ Institute for History, Universiteit Leiden
}

For someone so home-loving, someone with such a well-defined feeling for place, someone whose work consisted to a large extent of the history of his own environment, Johan Huizinga had a mental existence that was quite nomadic. "In the world of Buddhism there are entire countries still open to research", he said at the end of the public lecture which inaugurated his position as private lecturer at the University of Amsterdam. "Personally, I would prefer to wander along its long frontiers, where [the study of Buddhism] touches on the general study of civilisation, the art of China and Japan, the history of Hellenism in the East, and Early Christian culture." ${ }^{\prime}$

In fact his wanderings took him to less exotic places. But as a reader he remained, especially in view of the current myopic perspective of specialized historians, a wanderer. So was André Jolles, in an even more emphatic way. A wandering scholar, there is no better way to characterise Jolles, a vagrant between cultures, between climates of opinion, but also literally, between positions and homes. ${ }^{2}$ Where Huizinga turned out to be stability itself, Jolles had, in the end, lost his bearings.

I. J. Huizinga, “Over studie en waardeering van het Buddhisme”, in Verzamelde Werken I, Haarlem, Tjeenk Willink, I948, pp. I48-73; quotation: p. I72: "Ik voor mij zou het liefst blijven zwerven op hare uitgestrekte grenzen: daar waar zij raakt aan de algemeene beschavingskunde, aan de kunst van China en Japan, aan de geschiedenis van het Hellenisme in het Oosten, aan de Oud-Christelijke cultuur." (Translations from Huizinga’s works are taken from W. Otterspeer, Reading Huizinga, Amsterdam, Amsterdam University Press, 20Io, and are from the hand of Beverley Jackson; translations from Jolles are mine.)

2. The priceless collection of Jolles' letters and documents edited by Walter Thys was aptly subtitled "Gebildeter Vagant". "Eingebildeter Vagant" was the ironic self-characterization of Jolles, in a letter to Herman Nohl. See W. Thys (ed.), André Jolles (1874-1946), 'gebildeter Vagant'. Brieven en documenten, Amsterdam, Leipzig, Amsterdam University Press, Leipziger Universitätsverlag, 2000, p. 7. 
Where Huizinga succeeded in almost anything he did-he found happiness in marriage twice, his career brought him recognition in the Netherlands as well as abroad-Jolles was unhappy in almost everything he did. ${ }^{3}$ His greater brilliance-Huizinga would be the first to admit it - was only recognised after his death. Both men were conservative by nature. But where happiness seasoned Huizinga's conservatism with a fine flavour of nostalgia, Jolles' conservatism became revolutionary: he became a national socialist. ${ }^{4}$ It was the end of a wonderful friendship, of a bios parallellos, as Jolles rightly called it. ${ }^{5}$

Huizinga and Jolles were scholars with whom one can still enter into dialogue. I think that this is partially due to the fact that they wrote as real readers, as if they pursued their scholarship as remembrance of things past. It is then possible to write a book about Huizinga and Jolles mainly as readers, as people who find themselves while losing themselves, people who both choose and are chosen.

Huizinga was a reader-writer, and as such he was part of a long tradition. As a reader, Huizinga was a member of a strange and relatively small philological circle, the relic of what had once been the Respublica Literaria, that of comparative literature, readers of the most important languages of Ancient Europe, and in this way the re-creators of the even more ancient unity of the Latinitas from which colloquial Latin originated. Readers who were forced to acknowledge that what had once split into different languages was now disintegrating further as a result of illiteracy.

One of the most important branches of this family of readers was Romanic philology in Germany, with Friedrich Christian Diez and Leopold von Ranke as its founding fathers. It blossomed in the beginning of the Twentieth century with scholars such as Vossler, Curtius, Spitzer and Auerbach. ${ }^{6}$ There is of course a brilliant counterpart to this tradition in French and Italian Germanistik. In his breath-taking book Microcosmi Claudio Magris in wonderful vignettes sketches the great Italian masters

3. On Huizinga, see A. van der Lem, Johan Huizinga. Leven en werk in beelden \& documenten, Amsterdam, Wereldbibliotheek, I993; on Jolles, A. Bodar, De schoonheidsleer van André Jolles. Morphologische beschouwingen, PHD thesis, University of Amsterdam, 1987, but also chapter 9, "De tovenaar: André Jolles", in A. van der Lem, Johan Huizinga, op. cit., pp. 193-2II.

4. On mai I, I933, Jolles became a member of the NSDAP. His membership number was 2989023. See A. Bodar, De schoonheidsleer van André Jolles, op. cit., p. 23 and n. 59.

5. On the end of this friendship, see W. Thys, "Waarom gingen Johan Huizinga en André Jolles in I933 uit elkaar? Twee scenario's”, Internationale Neerlandistiek, 52, I, 20I4, pp. 67-80.

6. See H. U. Gumbrecht, Vom Leben und Sterben der grossen Romanisten. Carl Vossler, Ernst Robert Curtius, Leo Spitzer, Erich Auerbach, Werner Krauss, München, Wien, Carl Hanser Verlag, 2002. 
of this trade, Arturo Graf, Paolo Raffaele Troiano, Farinelli, Vincenti, describing not so much a course of study as a life's fulfilment. ${ }^{7}$

Here, as a background for the creative erudition of both Huizinga and Jolles, the presentation of a triumvirate suffices: Ernst Robert Curtius, Leo Spitzer and Erich Auerbach. I will focus on four similarities between them: an assumption, an experience, an analysis and a tool. Their common assumption was that culture was defined by harmony, by the unity and inseparability of the hearts and minds of its participants. This unity gave a culture its metaphysical aura, it was a musical harmony of the individual soul with the cosmos. They believed that this harmony once existed, and that it, quite recently, had been radically disturbed. ${ }^{8}$

Their scholarly attitude was in a way an answer to their cultural criticism. They were all passionate about language, and all of them had an exceptional linguistic sensibility and command. They were called philologists, but deplored the division between linguistics and literary theory, between philology and history, between history and the humanities, a division that had quickly unfolded in their lifetime. This process of specialization formed part of a much more general process of the dismantling of culture, and it drove each of them to combine in their work cultural-historical distance with cultural-critical involvement.

The feeling of unity that they cherished with respect to culture, whether that of Europe, of Christianity or of even greater entities, provided them with a rather wayward methodological assumption, which can best be described as a form of homeopathy. Where everything was linked, a secret affinity arose, and those who could sense it were able to find it again in every given thing, down to the smallest detail. The insight into this connectedness often came in the form of an epiphany, a shock, or a flash. All three of them adhered to what they called "a sense of quality", the theory of essential details or privileged aspects, the insight into a mysterious economy of part and whole that cannot be otherwise defined. "Sie müssen einen aufleuchten", in the words of Curtius. It was all about "the inner click", according to Spitzer. ${ }^{9}$

7. C. Magris, Microcosmi, Milano, Garzanti, 1997. (English translation: Microcosms, London, Harvill, 1999. Translated by I. Halliday.)

8. I took the inspiration for my essay from J. Kamerbeek Jr., "Johan Huizinga und Ernst Robert Curtius. Versuch einer vergleichenden Characteristik", in Johan Huizinga I872-1972, Den Haag, Nijhoff, 1973, pp. I75-92; see also my essay "Eén druppel wijn. Lezen en werk van J. Kamerbeek Jr.", Nexus, 5, 1993, pp. 52-76.

9. E. R. Curtius, Französischer Geist im neuen Europa, Berlin, Leipzig, Deutsche Verlagsanstalt, 1925, pp. I6-7; L. Spitzer, Linguistics and Literary History. Essays in Stylistics, Princeton, Princeton University Press, I967, p. 7. 
It was, above all, the ability to see the abstract in the concrete. They used, in the happy phrase of Spitzer, "warm abstractions", abstractions that are visible and, rather than being used to sever our bonds with life, are organic and remain close to the body. It is this ability that forms the basis for Auerbach's masterwork, Mimesis. In the scar of Odysseus and the sacrifice of Isaac, Auerbach is able to point to two basic stylistic types that were given to European literature by Homer and the Elohist. ${ }^{10}$

The connection between part and whole, between detail and totality, intrigued them it the utmost way. And all of them assumed a fairly similar description of that relationship in their definition of "form". Curtius used the notion of "intellectual constitution", Spitzer that of "inner form" and "inner life centre". "The lifeblood of poetic imagination is everywhere the same," says Spitzer, "whether we are tapping the organism for 'language' or 'ideas', 'plot' or 'composition'." II

This allowed them to create the visionary typology of which Auerbach's Mimesis is a textbook example. "The two styles, in their opposition", Auerbach writes about the differences between Homer and the Elohist, "represent basic types". Complete description contrasts with selection, clarity with suggestion, surface with depth, simplicity with complexity. And this focus on contrast, this creation of a "table of antinomies" is a fundamental component of the method of these literary theorists. ${ }^{\mathrm{I2}}$

Curtius for instance traces, in his Europäische Literatur und lateinisches Mittelalter, the two Kulturkörpern of European culture, contrasting the old Mediterranean and the modern Western ("abendländische") characters only to ultimately reunite them into a single frame and reveal their deep underlying continuity. ${ }^{13}$ In his Classical and Christian Ideas of World Harmony, Spitzer opposes changeability and permanence, atmosphere and environment, subjectivity and objectivity, to ultimately find harmony as a "dialectics of integrated contrasts". ${ }^{\text {I4 }}$

Nothing is stable in the world of human creation and what the philologist is essentially doing is, to use once again Spitzer's words, "surrendering to a

Io. E. Auerbach, Die Narbe des Odysseus, in Mimesis. Dargestellte Wirklichkeit in der abendländischen Literatur, Bern, München, Francke, I97I, pp. 5-28.

II. On Curtius: M. Kowal, Introduction, in E. R. Curtius, Essays on European Literature, Princeton, Princeton University Press, 1973, pp. IX-Xxıv; quotation: p. XIII; L. Spitzer, Linguistics and Literary History, op. cit., p. I8.

I2. E. Auerbach, Mimesis, op. cit., p. 23. On the notion of "table of antinomies", see J. Kamerbeek Jr., "Huizinga en de beweging van Tachtig", Tijdschrift voor Geschiedenis, 67, 1954, p. I47.

I3. E. R. Curtius, Europäische Literatur und lateinisches Mittelalter, Bern, München, Francke, 1973, p. I9.

I4. L. Spitzer, Classical and Christian Ideas of World Harmony. Prolegomena to an Interpretation of the Word "Stimmung", Baltimore, The Johns Hopkins University Press, 1963, p. 9. 
propensity to see things as shifting and melting into each other." ${ }^{\text {Is }}$ Curtius used the metaphor of rivers flowing into each other, "wie wenn der Rhein die Wasser des Tibers aufgenommen hätte." "Wortwandel ist Kulturwandel und Seelenwandel." " Auerbach said it in his Philology and Weltliteratur [Philologie der Weltliteratur]: "The inner history of the last thousand years is the history of mankind achieving self-expression: this is what philology, a historical discipline, treats." ${ }^{17}$

It is undoubtedly also Auerbach who formulates most transparently this intensely Pythagorean way of thinking with his notion of figura. Figura is the concept in which everything on earth finds its completion and fulfilment in the hereafter. This form of philology, which looks exactly like the typological interpretation of the Old Testament-every person and every story finds its fulfilment in the New Testament-immediately makes it clear how easy it was to translate Pythagorean mysticism into Christian ideas, and it explains the magnificent continuity of thought. ${ }^{18}$

It also explains why these authors, not only Auerbach, but also Curtius and Spitzer, were cultural critics. Deeply convinced as they were that philology was not an antiquarian discipline but rather the study of the past at the service of the present, they noticed a dramatic rupture in style, which through fragmentation and flattening, specialization and standardization, separated the modernity of the Nineteenth century from the two thousand years of unity that had preceded it as by a watershed. In their common aversion to progress and Positivism, these Cassandra types saw it as their task to once again turn their eyes to the magnificent unity of European culture which was collapsing under their feet.

This also makes their books individual testaments. Mimesis was a book, "written in the early I940s by a certain person, in a certain situation". Auerbach wrote it, dismissed from Marburg and driven out of Germany, in Istanbul. ${ }^{19}$ Curtius was not a Jew and he was allowed to remain in Germany, but he was nevertheless writing against the background of "the crisis of European culture" revealed by the First World War. In his book

15. L. Spitzer, Linguistics and Literary History, op. cit., p. 9.

I6. E. R. Curtius, Europäische Literatur und lateinisches Mittelalter, op. cit., pp. 8-9.

17. See J. M. Ziolkowski, Foreword, in E. Auerbach, Literary Language and Its Public in Late Latin Antiquity and the Middle Ages, Princeton, Princeton University Press, I993, pp. IX-Xxxix; quotation: p. Xx.

I8. E. Auerbach, "Figura", in J. I. Porter (ed.), Time, History, and Literature. Selected Essays of Erich Auerbach, Princeton, Oxford, Princeton University Press, 20I4, pp. 65-II4. (Translated by J. O. Newman.) See also E. Auerbach, Figura, Paris, Macula, 2003. (Translated by D. Meur, with an excellent postface by M. de Launay.)

19. See also the Introduction to the Fiftieth-Anniversary Edition, by E. Said, in E. Auerbach, Mimesis, Princeton, Oxford, Princeton University Press, 2003, pp. IX-XXXIII. 
on Balzac, he talks about the aesthetics of art for art's sake as the reaction of the artistic and humanistic instinct against the rupture in style that characterised art in the Nineteenth century. ${ }^{20}$

And Spitzer? Another victim of the diaspora, he wrote his book on World Harmony at Yale. The field of meaning that he describes had disappeared, and its disappearance was simply "the history of modern civilisation", the history of a disenchantment or unchristening. He pleaded for a new periodization of Western history. For him, the breech did not come with the Renaissance. It was only after the Baroque that the field defining the concepts of mood and harmony was "radically uprooted". At the end of the Eighteenth century, Harmony had become frozen and robbed of its flowers. ${ }^{2 \mathrm{I}}$

A dual biography of Huizinga and Jolles is thus necessary. Not a proper biography, actually, but rather the recreation of an "intellectual constitution", the growth of a "spiritual person", split in two halves, contrasting identities that for a few decades found a middle ground of exhilarating creativity. ${ }^{22}$ For the remainder of this essay, I will concentrate on only one small aspect of this creativity, the ideas of both Huizinga and Jolles about transformation, about metamorphosis, as the inner mechanism of cultural change.

For both of them the notion of form was a trait d'union between mutable life and immutable human nature. Life existed in infinite variations, forms were limited in number, while the essence of man remained virtually constant. In what they both described as their morphology, Huizinga as well as Jolles was trying to trace not a linear development, but a metamorphosis of forms, forms which adapted themselves to the central principle of the culture that makes use of them.

At several points in his oeuvre Huizinga for instance refers to standard psychological figures that incorporate both elementary ways of seeing and social roles that readily transform into each other. One of those series was about the creative persona. "Our intellect is still capable", he wrote in The Autumn of the Middle Ages about the capacity of seeing colours as symbolic essences, "of seeing things in this way at any time, if we can momentarily capture the wisdom of primitive man, the child, the poet, or

20. See M. Kowal, Introduction, op. cit., pp. XVI-XviI.

21. L. Spitzer, Classical and Christian Ideas of World Harmony, op. cit., pp. 75-6.

22. To go into real detail here is impossible but for a good idea of my working method I can refer to W. Otterspeer, Reading Huizinga, op. cit. 
the mystic. For all these, the natural essence of things is locked up in their general quality". ${ }^{23}$

In his major essay on Spengler and Wells, "Two Wrestlers with the Angel", he describes two ways of understanding the world: "that of the immediate awareness of things in their totality and in their interrelatedness, the apprehension of their intrinsic nature and shape, of seeing things in [the context of] time, in their supernatural fullness of significance, in their eternal motion and their tragic fatality. It is the way in which primitive man, the child and the poet understand the world". The second way developed only at a later stage of culture: "seeing things in their isolation, in [the context of] space, analyzing, measuring, calculating, systematizing, solving all mysteries with the category of causality". ${ }^{24}$

Later still, in Homo ludens, Huizinga applies this primitive, original approach to poetry itself. "If a serious statement is defined as one that may be made in terms of waking life, poetry will never rise to the level of seriousness. It lies beyond seriousness, on that more primitive and original level where the child, the animal, the savage and the seer belong, in the region of dream, enchantment, ecstasy, laughter." 25

The whole text of Homo ludens is geared towards dissolving the distinction between child and primitive man. The child is one with his play, just as the primitive man, in his magic dance, becomes the kangaroo. "It is a mystic unity. The one has become the other." This metamorphosis too is based on the dynamics of the fairy-tale. "In this sphere of sacred play the child and

23. J. Huizinga, Herfsttij der Middeleeuwen. Studie over levens- en gedachtenvormen der veertiende en vijftiende eeuw in Frankrijk en de Nederlanden, in Verzamelde Werken III, Haarlem, Tjeenk Willink, I949, pp. 3-436; quotation: p. 248 ("Ook òns denken vermag nog elk oogenblik ze zoo te zien, als het maar even terugkeert tot de wijsheid van den wilde, het kind, den dichter en den mysticus, voor wie de natuurlijke gesteldheid der dingen ligt opgesloten in hun algemeene hoedanigheid." (English quotation from J. Huizinga, The Autumn of the Middle Ages, Chicago, University of Chicago Press, 1996, p. 37. Translated by R. J. Payton and U. Mammitzsch.)

24. J. Huizinga, "Twee worstelaars met den engel (bespreking van Oswald Spengler's Der Untergang des Abendlandes en H. G. Wells' The Outline of History”, in Verzamelde Werken IV, Haarlem, Tjeenk Willink, 1949, pp. 44I-97; quotation: p. 446. ("Twee wijzen zijn het dus, om de wereld te begrijpen: de eene die van het onmiddellijke in hun geheelheid en verwikkeldheid beseffen der dingen, het vatten van den eigen aard, de eigen gestalte der dingen, het zien der dingen in den tijd, in hun daemonische volheid van beteekenis, in hun eeuwig bewegen en hun tragische fataliteit. Het is de wijze, waarop de primitieve mensch, het kind, de dichter de wereld begrijpt.")

25. J. Huizinga, Homo ludens. Proeve eener bepaling van het spelelement der cultuur, in Verzamelde Werken V, Haarlem, Tjeenk Willink, I950, pp. 26-247; quotation: p. I48 ("Wanneer men ernst opvat als datgene, wat zich in de termen van het wakende leven sluitend laat uitdrukken, dan wordt poëzie nooit volkomen ernstig. $\mathrm{Zij}$ staat aan gene zijde van den ernst, aan de oorspronkelijke zijde, waar het kind, het dier, de wilde en de ziener thuishooren, in het veld van den droom, de vervoering en den lach." (English quotation from J. Huizinga, Homo Ludens. A Study of the Play-Element in Culture, Boston, Beacon, I955, p. II9. Translated by R. F. C. Hull.) 
the poet are at home with the savage." And it is "aesthetic sensibility" that has "brought the modern man closer to this sphere". ${ }^{26}$

The second filiation is social and connects a Greek ideal of upbringing, through a number of links, to a Nineteenth-century view of the exemplary role of the upper middle classes. The ideal is kalokagathia, a term coined from the Greek words for good and beautiful, $\kappa \alpha \lambda o ́ \varsigma$ and $\alpha \gamma \alpha \theta \dot{s} \varsigma$. The connections are made explicit in Homo ludens: "A direct line runs from the knight to the 'honnête homme' of the i7th century and the modern gentleman. The Latin countries of the West added to this cult the ideal of the gallant, so that chivalry and courteous love are so interwoven that we can hardly tell which is warp and which woof." ${ }^{27}$

Earlier, in The Autumn of the Middle Ages, he had described chivalry as "a social, ethical and aesthetic necessity". The power of the ideal lay in its exaggeration, which at the same time sapped its vigour. The new era jettisoned the overly high-pitched aspirations. "The knight is transformed into the French gentilhomme of the seventeenth century, who, though still maintaining a number of concepts of state and honor, no longer claims to be a warrior for matters of faith or a defender of the weak and oppressed. The place of the type of French nobleman is taken-modified and refined-by the 'gentleman', who is derived directly from the type of the old knight. During the successive transformations of the ideal the outermost shells, each having become a lie, are peeled away time and again." ${ }^{28}$

In October 193I Jolles held a lecture for three Dutch universities, that was published in German under the title "Die literarische Travestien. Ritter-Hirt-Schelm". ${ }^{29}$ Like the series of Huizinga, these identities were both elementary attitudes and social roles. They could spill over into

26. "Het is een mystische identiteit. De een is het ander geworden. De wilde, in zijn tooverdans, is kangaroe." (J. Huizinga, Homo ludens, op. cit., p. 53 . English translation, op. cit., p. 25.)

27. "Van den ridder over den 'honnête homme' der zeventiende eeuw tot den modernen gentleman loopt een rechte lijn. Het Latijnsche Westen heeft in dien cultus van het edele krijgersleven ook het ideaal van hoofsche minne opgenomen, het is er zoo innig door heen geweven, dat op den duur de inslag de schering verborg." (J. Huizinga, Homo ludens, op. cit., p. I33. English translation, op. cit., p. I04.)

28. "De ridder gaat over in den Franschen gentilhomme der zeventiende eeeuw, die nog wel een stel stands- en eerbegrippen onderhoudt, maar zich niet meer uitgeeft voor een strijder voor het geloof, een verdediger van zwakken en verdrukten. Voor het Fransche edelmanstype treedt dat van den gentleman in de plaats, regelrecht ontwikkeld uit den ouden ridder, maar getemperd en verfijnd. Bij de opeenvolgende transformaties van het ideaal liet telkens een buitenste schaal, die leugen geworden was, los." (J. Huizinga, Herfsttij der Middeleeuwen, op. cit., p. I27. English translation, op. cit., pp. II9-20.)

29. "The literary travesty. Knight-Shepherd-Knave." A. Jolles, "Die literarischen Travestien, RitterHirt-Schelm”, Blätter für deutsche Philosophie, 6, 3, 1932, pp. 28I-94; reprinted in H. Heidenreich (ed.), Pikarische Welt. Schriften zum europäischen Schelmenroman. Wege der Forschung, vol. CLXIII, Darmstadt, Wissenschaftliche Buchgesellschaft, I969, pp. 28I-94. 
one another and they were both literature-genres such as the heroic, the bucolic and the picaresque - and realities_our confrontation with culture.

"Kerngruppen", Jolles dubs them, essential attitudes in a cultural repertoire. They incorporate the three varieties of change-Verwandlung in German - that are open to us: transitive, intransitive and reflexive, that is active (to change, to take on another identity), passive (to be changed, to be invaded by another identity) and a third possibility in between (Jolles uses here the German Verkleidung, a less radical change in which we keep our identity more or less intact). All of them are travesties, movements either upward (the knight), downward (the knave), or outward (the bucolic, the shepherd).

Jolles here also reflects on his theory of culture. Whether literary genres or social attitudes, the three travesties are a form of play. The travesty of the shepherd is a play with nature, the travesty of the knight is a play with the heroic, the travesty of the knave is a play with crime. Play, according to Jolles, is a world with its own demands and its own laws: "Eine Welt mit eigenen Erfordernissen und eigener Gesetzlichkeit." ${ }^{\circ}$ Two years later Huizinga, in his rectoral address on the dies natalis of Leiden university (February 8, 1933), would define play as the creation of "a completely fenced off, enclosed world in which the players move according to its own constraining law". ${ }^{3}$

So, here we have the announcements of two seminal books, Einfache Formen on the one hand, and Homo ludens on the other, and we see the bioi parallelloi of both writers characterised by a common creativity and clarity, an essential preconception and postulate. ${ }^{32}$ But the richness of the bioi parallelloi not only lies in the detection of similarities, they also show the differences. And there is a fundamental one here at work.

Huizinga recognised the heart of culture in play. All culture was preceded by play, born as play and in play. But for Jolles play was at the same time essence and avoidance, "Quintessence und Abfall". The three forms he described were forms of escape from culture, the only three available to mankind. Upward, downward or outside, these were the three possibilities of the flight from culture, of "Kulturflucht". "Somehow or

30. "A world with its own requirements and its own patterns." (A. Jolles, "Die literarische Travestien", art. cit., p. 292.)

3I. "Een eigen, uitzonderlijke, omheinde wereld binnen de gewone." (J. Huizinga, "Over de grenzen van spel en ernst in de cultuur", in Verzamelde Werken V, Haarlem, Tjeenk Willink, 1950, pp. 3-26; quotation: p. 5.)

32. A. Jolles, Einfache Formen. Legende, Sage, Mythe, Rätsel, Spruch, Kasus, Memorabile, Märchen, Witz, Tübingen, Max Niemeyer Verlag, I930; J. Huizinga, Homo ludens, op. cit. 
other culture weighs on us, depresses us," he writes, "its so called blessings harass and torment us." "The knight, the knave and the shepherd, they are the three safety valves of our culture." 33

Here we see a fundamental difference between the thought of Jolles and that of Huizinga. According to Jolles, man has the possibility to order the dazzling variety of life according to certain literary principles. Every human being has that possibility, and that's why he likes to treat literature as a sort of energy more than as a result. And there are again two possibilities: either literature moulds life or life models literature. It is here that the parallel lives of Huizinga and Jolles part. Here, essentially, their two roads diverged. Jolles in the end took the first option, Huizinga the second one. Huizinga chose life, Jolles literature. Jolles took the road less travelled by, and that made all the difference.

33. "Irgendwie beschwert und bedrückt uns unsere Kulturwelt, ihre sogenannten Wohltaten quälen und verletzen uns." "Ritter, Hirt, Schelm sind die drei Sicherheitsventile unserer Kultur." (A. Jolles, "Die literarischen Travestien”, art. cit., pp. 288 and 293.) 